University of Nebraska - Lincoln

DigitalCommons@University of Nebraska - Lincoln

Civil Engineering Faculty Publications

Civil Engineering

2012

Removing $17 \beta$-estradiol from drinking water in a biologically active carbon (BAC) reactor modified from a granular activated carbon (GAC) reactor

Zhongtian Li

University of Nebraska - Lincoln, li.zhongtian3988@huskers.unl.edu

Bruce I. Dvorak

University of Nebraska-Lincoln, bdvorak1@unl.edu

$\mathrm{Xu} \mathrm{Li}$

University of Nebraska-Lincoln, xuli@unl.edu

Follow this and additional works at: http:// digitalcommons.unl.edu/civilengfacpub

Li, Zhongtian; Dvorak, Bruce I.; and Li, Xu, "Removing 17 $\beta$-estradiol from drinking water in a biologically active carbon (BAC) reactor modified from a granular activated carbon (GAC) reactor" (2012). Civil Engineering Faculty Publications. 60.

http://digitalcommons.unl.edu/civilengfacpub/60

This Article is brought to you for free and open access by the Civil Engineering at DigitalCommons@University of Nebraska - Lincoln. It has been accepted for inclusion in Civil Engineering Faculty Publications by an authorized administrator of DigitalCommons@University of Nebraska - Lincoln. 


\title{
Removing $17 \beta$-estradiol from drinking water in a biologically active carbon (BAC) reactor modified from a granular activated carbon (GAC) reactor
}

\author{
Zhongtian Li, Bruce Dvorak, and Xu Li \\ Department of Civil Engineering, University of Nebraska-Lincoln, \\ 844 N. 16th St., N117 SEC Link, Lincoln, NE 68588-6105, USA \\ Corresponding author - X. Li, email xli4@unl.edu
}

\begin{abstract}
Estrogenic compounds in drinking water sources pose potential threats to human health. Treatment technologies are needed to effectively remove these compounds for the production of safe drinking water. In this study, GAC adsorption was first tested for its ability to remove a model estrogenic compound, $17 \beta$-estradiol (E2). Although GAC showed a relatively high adsorption capacity for $E 2$ in isotherm experiments, it appeared to have a long mass transfer zone in a GAC column reactor, causing an early leakage of $E 2$ in the effluent. With an influent $E 2$ concentration of $20 \mu \mathrm{g} / \mathrm{L}$, the GAC reactor was able to bring down effluent $E 2$ to $\sim 200 \mathrm{ng} / \mathrm{L}$. To further enhance $E 2$ removal, the GAC reactor was converted to a biologically active carbon (BAC) reactor by promoting biofilm growth in the reactor. Under optimal operating conditions, the $B A C$ reactor had an effluent $E 2$ concentration of $\sim 50 \mathrm{ng} / \mathrm{L}$. With the empty bed contact times tested, the reactor exhibited more robust $E 2$ removal performance under the BAC operation than under the GAC operation. It is noted that estrone (E1), an $E 2$ biodegradation intermediate, was frequently detected in reactor effluent during the BAC operation. Results from this study suggested that BAC could be an effective drinking water treatment process for $E 2$ removal and in the meantime $E 1$ accumulation needs to be addressed.
\end{abstract}

Keywords: $17 \beta$-estradiol, Estrone, GAC adsorption, Biologically active carbon

\section{Introduction}

The detection of natural estrogens in water has caused increasing concerns over their health impacts on human beings and aquatic ecosystems. $17 \beta$-estradiol (E2) is one of the strongest natural estrogens based on a yeast estrogenicity screening assay (Metcalfe et al., 2001; Rutishauser et al., 2004). E2 can cause adverse health impacts on the reproduction system of male fish at a few tens of ng/L (Imai et al., 2005; Purdom et al., 1994). Recent surveys in North America, Europe, and Asia detected E2 in surface water and ground water with concentrations up to $70 \mathrm{ng} / \mathrm{L}$
(Benotti et al., 2009b; Kim et al., 2007; Labadie and Budzinski, 2005; Loos, 2010). In lagoons treating wastewater from concentrated animal feeding operations $E 2$ concentration can be as high as $21 \mu \mathrm{g} / \mathrm{L}$ (Hutchins et al., 2007). US EPA recently added E2, along with two other natural estrogens estrone (E1) and estriol (E3), onto its Contaminant Candidate List 3 (EPA, 2011).

Estrogens may be removed from water through physicochemical treatment processes, such as membrane separation (Benotti et al., 2009a; Cartinella et al., 2006; Yoon et al., 2007) and advanced oxidation (Hansen et al., 2010; Maniero et al., 2008; Shappell et al., 2008). Granular activated carbon 
(GAC) adsorption is also a viable option. The removal efficiencies of GAC on estrogens have been tested in laboratory-scale batch reactors and continuous flow filters, and surveyed in full-scale filtration plants (Benotti et al., 2009b; Fukuhara et al., 2006; Zhang and Zhou, 2005). Although virgin GAC often has high adsorption capacities, the presence of other constituents in water, such as natural organic matter (NOM), could significantly reduce the GAC adsorption capacity for estrogens (Fukuhara et al., 2006). Fukuhara and co-workers showed that the GAC adsorption capacity for $E 2$ in river water was about one thousandth of that for $E 2$ in pure water. They attributed the reduction in GAC adsorption capacity for $E 2$ to the site competition and pore blockage that occurred on GAC surface due to the presence of constituents, often at concentrations much higher than estrogen concentrations, in river water.

Natural estrogens may also be degraded through microbial activities. Although microbial degradation of estrogens has not been investigated in the context of drinking water treatment, studies on wastewater treatment showed that activated sludge process could often degrade E2 (Holbrook et al., 2002; Kuster et al., 2010; Stanford and Weinberg, 2010). Phylogenetic analyses showed that estrogen degrading bacteria belong to multiple genera, e.g., Sphingomonas, Aminobacter, and Rhodococcus (Fujii et al., 2002; Yoshimoto et al., 2004; Yu et al., 2007). Many E2 degrading bacteria can convert $E 2$ to $E 1$, but cannot further degrade $E 1$, therefore, $E 1$ is a commonly detected $E 2$ degradation intermediate (Yu et al., 2007). One interesting finding is that many estrogen degrading bacteria species were isolated from nitrifying activated sludge, which led to the speculation that enzymes involved in nitrification may be responsible for estrogen degradation (Shi et al., 2004; Vader et al., 2000; Yi and Harper, 2007).

Biologically active carbon (BAC) is GAC covered with biofilm. The dual mechanism of GAC adsorption and microbial degradation makes BAC filters a potential treatment technology to remove low-level estrogens during drinking water treatment. An early study showed that BAC filters had better performance of removing intermittently spiked E2 in water than did GAC filters (Li et al., 2008). To assess their feasibility to treat estrogen-contaminated water, BAC filters need to be operated under continuous flow mode and be tested for their ability to remove estrogens that are constantly present in influent. Besides, the $E 2$ removal efficiency of BAC needs to be systematically tested under various reactor operating conditions.

The objective of this study was to investigate the feasibility of the BAC process to remove $E 2$ from drinking water and to study the impacts of various reactor operating conditions on estrogen removal efficiency. The reactor operating conditions included varying nutrient addition and adjusting the empty bed contact time (EBCT). The difference of $E 2$ removal efficiency between GAC and BAC was systematically studied. Through the operation of a laboratory-scale reactor system with an extended period, this study provides useful information in assessing the feasibility of BAC to remove estrogens from drinking water in full-scale systems.

\section{Materials and methods}

\subsection{Chemicals}

$17 \beta$-estradiol, estrone, $17 \beta$-estradiol-16, 16, 17- $\mathrm{d}_{3}$ (purity $\geq 98 \%$ ), and derivatization grade N,O-Bis(trimethylsilyl)trifluoroacetamide (BSTFA) containing 1\% trimethylchlorosilaneacetic (TMCS) acid were purchased from Sigma-Aldrich (St. Louis, MO). HPLC-grade anhydrous methanol, acetone, ethyl acetate, dimethyl formamide, and phenanthrene were purchased from Fisher Scientific (Pittsburgh, PA).

\subsection{Adsorption kinetics and isotherm experiments}

Calgon Filtrasorb ${ }^{\circledR} 400$ (F400) coal-based GAC was washed with Nanopure water 10 times to remove GAC fines prior to use. Dried GAC was either passed through a $30 \times 40$ mesh or ground using an analytical mill and sieved through a $200 \times 350$ mesh (Putz et al., 2005). Both GAC and ground GAC were dried at $105^{\circ} \mathrm{C}$ for $24 \mathrm{~h}$ and stored in a sealed glass desiccator until use (Speitel and Digiano, 1987).

Adsorption kinetics and isotherm experiments were conducted in pH 7.4 phosphate buffer saline (PBS) in amber glass bottles. Estrogen stock solutions in methanol were spiked into sterilized PBS to predetermined concentrations. In adsorption kinetics experiments, $\sim 6 \mathrm{mg}$ of GAC or ground GAC was added to each bottle, which had an initial $E 2$ concentration of $200 \mu \mathrm{g} / \mathrm{L}$. Each bottle was tumbled at $80 \mathrm{rpm}$ in dark and five 1-mm diameter glass beads was added to each bottle to ensure thorough mixing. Adsorption isotherm experiments were conducted for $E 1$ and $E 2$ in both single- and dual-solute solutions. The amount of estrogen spiked to each $500-\mathrm{mL}$ bottle ranged from 7.5 to $400 \mu \mathrm{g}$. Each bottle contained $\sim 6 \mathrm{mg}$ ground GAC. For each sampling event, $100 \mathrm{~mL}$ water sample was centrifuged at 5,000 rpm for $15 \mathrm{~min}$ to remove activated carbon particles. $50 \mathrm{~mL}$ supernatant was collected and stored at $-20^{\circ} \mathrm{C}$ until analysis.

\subsection{Reactor setup}

A glass column with a $5 \mathrm{~cm}$ inner diameter and a $45 \mathrm{~cm}$ length was made by ACE Glass (Vineland, NJ) and packed with $270 \mathrm{~g}$ virgin F400 GAC resulting a $12.2 \mathrm{~cm}$ bed depth. Water treated by an in-house reverse osmosis (RO) system was used to prepare reactor influent. The $\mathrm{RO}$ water had a $\mathrm{pH}$ between 6.9 and 7.2 and a total organic carbon (TOC) level fluctuating between 0.4 and $0.8 \mathrm{mg} / \mathrm{L}$. A $48 \mathrm{~L}$ glass bottle wrapped with aluminum foil was used to store water containing $E 2$, while a $200 \mathrm{~L}$ polypropylene tank to store water containing other constituents in synthetic water (Nerenberg et al., 2002). The influent composition is summarized in Table 1. Teflon tubings were used to connect components of the reactor system. Different EBCTs were achieved by varying the flow rate. The $\mathrm{pH}$ values of reactor influent and effluent were monitored to be 6.8-7.2 throughout the experiment. 
Table 1. The composition of the influent to the reactor system.

\begin{tabular}{lc}
\hline Chemical $^{\text {a }}$ & Concentration $(\mathbf{m g} / \mathbf{L})$ \\
\hline$E 2^{\mathrm{b}}$ & 0.02 \\
$\mathrm{Na}_{2} \mathrm{HPO}_{4}$ & 142 \\
$\mathrm{KH}_{2} \mathrm{PO}_{4}$ & 136 \\
$\mathrm{NaHCO}_{3}$ & 5.1 \\
$\mathrm{MgSO}_{4} \cdot 7 \mathrm{H}_{2} \mathrm{O}$ & 200 \\
$\mathrm{CaCl}_{2} \cdot 2 \mathrm{H}_{2} \mathrm{O}$ & 1 \\
$\mathrm{FeSO}_{4} \cdot 7 \mathrm{H}_{2} \mathrm{O}$ & 1 \\
$\mathrm{EDTA}$ & 3 \\
$\mathrm{ZnSO}_{4} \cdot 7 \mathrm{H}_{2} \mathrm{O}$ & 1 \\
$\mathrm{MnCl}_{2} \cdot 4 \mathrm{H}_{2} \mathrm{O}$ & 0.3 \\
$\mathrm{H}_{3} \mathrm{BO}_{3}$ & 3 \\
$\mathrm{CoCl}_{2} \cdot 6 \mathrm{H}_{2} \mathrm{O}$ & 0.2 \\
$\mathrm{CuCl}_{2} \cdot 2 \mathrm{H}_{2} \mathrm{O}$ & 0.1 \\
$\mathrm{NiCl}_{2} \cdot 6 \mathrm{H}_{2} \mathrm{O}$ & 0.2 \\
$\mathrm{Na}_{2} \mathrm{MoO}_{4} \cdot 2 \mathrm{H}_{2} \mathrm{O}$ & 0.3 \\
$\mathrm{NH}_{4} \mathrm{Cl}_{-} \mathrm{N}^{\mathrm{c}}$ & 3 \\
$\mathrm{NaNO}_{3}-\mathrm{N}^{\mathrm{d}}$ & 4 \\
$\mathrm{CH}_{3} \mathrm{COOH}-\mathrm{C}^{\mathrm{d}}$ & 5 \\
\hline
\end{tabular}

a. Day 178-Day 348, unless specified otherwise.

b. Day 0-Day 348.

c. Day 178-Day 240.

d. Day 240-Day 348.

\subsection{Reactor operations}

Before the GAC reactor received E2-containing influent, it was initially operated with only $\mathrm{RO}$ water until the effluent dissolved oxygen (DO) concentration stabilized between 7.8 and $8.2 \mathrm{mg} / \mathrm{L}$. In the first 178 days of operation $(13,174$ bed volumes, or BVs), the GAC reactor was fed an influent containing $20 \mu \mathrm{g} / \mathrm{L}$ E2. Although no microbial seeds or external substrates were added to the influent, microbial activities developed in the reactor toward the end of this operation period, which was evidenced by visual observation of biofilm and verified by the detection of $E 1$ in reactor effluent on Day 164 (12,602 BVs). Development of microbial activities in column tests without intentional seeding is not uncommon (Wang et al., 2007).

On Day 178, $3.0 \mathrm{mg} / \mathrm{L} \mathrm{NH}_{4}^{+}-\mathrm{N}$ along with other nutrients were added to reactor influent (Table 1). $\mathrm{NH}_{4}^{+}-\mathrm{N}, \mathrm{DO}$, and TOC were measured using a NitraVer ${ }^{\circledR} 5$ kit (Hach, USA), a DO meter (YSI Incorporated, USA), and an Apollo 9000 TOC analyzer (Teledyne, USA), respectively. On Day 240 , the $\mathrm{NH}_{4}^{+}-\mathrm{N}$ was replaced by $4.0 \mathrm{mg} / \mathrm{L} \mathrm{NH}_{3}^{-}-\mathrm{N}$ to better simulate the nitrogen source in natural surface water (Mitsch et al., 2005). In the meantime, $5.0 \mathrm{mg}-\mathrm{C} / \mathrm{L}$ acetic acid was added to reactor influent through a syringe pump to simulate the readily biodegradable portion of organic matters in surface water and to serve as the primary energy/carbon source for microbial growth in the reactor. We realized that $5.0 \mathrm{mg}-\mathrm{C} / \mathrm{L}$ acetic acid was higher than the readily biodegradable portion of NOM commonly found in natural water. In a fellow-up study (manuscript in preparation), we replaced the $5 \mathrm{mg}-\mathrm{C} / \mathrm{L}$ acetic acid with $5.0 \mathrm{mg}-\mathrm{C} / \mathrm{L}$ humic acid, which is a typical concentration to simulate NOM in natural water. This design allowed us to compare estrogen biodegradation in the presence of energy/carbon sources with different biodegradability but at the same concentration (i.e., $5 \mathrm{mg}-\mathrm{C} / \mathrm{L}$ acetic acid vs. $5 \mathrm{mg}-\mathrm{C} / \mathrm{L}$ humic acid). Backwashing was conducted every
25-30 days when head loss of the reactor exceeded 1.42 psi (measured by a pressure gauge). During backwash, the reactor was flushed with a mixture of $50 \mathrm{~mL} / \mathrm{min}$ water and $200 \mathrm{~mL} / \mathrm{min}$ air for $2 \mathrm{~min}$ and followed by $50 \mathrm{~mL} / \mathrm{min}$ water for $3 \mathrm{~min}$. Water samples for estrogen measurements were collected at least three days after each backwash event to allow reactor performance to stabilize.

\subsection{Estrogen measurements}

Estrogens were quantified in the UNL Water Sciences Laboratory. An HP5890 series gas chromatography (GC) equipped with a DB-5 capillary column and coupled with an Agilent 5972 quadrapole mass spectrometer (MS) was used to measure E1,E2, and E3 in water. A published protocol using BSTFA-TMCS derivatization was adapted and optimized for this study (Shareef et al., 2006). Essentially, water samples were spiked with $20 \mu \mathrm{L}$ of $10 \mathrm{mg} / \mathrm{L}$ $17 \beta$-estradiol-16, 16, 17- $\mathrm{d}_{3}$ as an internal standard and $20 \mu \mathrm{L}$ of $10 \mathrm{mg} / \mathrm{L}$ phenanthrene as a surrogate, and concentrated using a C-18 solid phase extraction (SPE) cartridge (Waters, USA). After eluted from the SPE cartridges by ethyl acetate, extracts were blown dry by nitrogen gas, reconstituted, and derivatized with $50 \mu \mathrm{L}$ dimethyl formamide and $50 \mu \mathrm{L}$ BSTFA $+1 \%$ TMCS at $75^{\circ} \mathrm{C}$ for $30 \mathrm{~min}$. Derivatized samples were equilibrated to the room temperature and transferred to GC vials with $250 \mu \mathrm{L}$ glass inserts. All samples were analyzed within $36 \mathrm{~h}$ after derivatization. A fivepoint standard curve was included in each GC-MS run. The method detection limit (MDL) for E1, E2, and E3 was determined to be $14.4,5.8$, and $11.4 \mathrm{ng} / \mathrm{L}$, respectively, by following a standard procedure (EPA, 1984). The average of duplicate measurements was reported for each sample.

\section{Results and discussion}

\subsection{Adsorption kinetics and isotherm}

Virgin GAC exhibited slow adsorption kinetics. In the kinetics experiments using GAC, E2 concentration continued to decrease after $144 \mathrm{~h}$, indicating adsorption equilibrium had not been reached (Figure 1). In contrast, in the kinetic experiments using ground GAC, adsorption equilibrium was reached in less than $82 \mathrm{~h}$. Because the adsorption capacity of GAC can be approximated using the adsorption capacity of the ground GAC of the same carbon (Putz et al., 2005), ground GAC was used in all subsequent isotherm experiments to assess the ultimate adsorption capacity of GAC F400 for estrogens.

The adsorption isotherm data can be well explained using the Freundlich isotherm equations (Figure 2). The $R^{2}$ values of the Freundlich isotherm simulation ranged between 0.91 and 0.99 (Table 2). $K_{F}$ describes adsorption capacity, while $1 / n$ denotes the abundance of high-energy adsorption sites on the activated carbon surface. In the single-solute experiments in which either E1 or E2 was the sole adsorbate, the $K_{F}$ value for $E 1$ was $65 \%$ higher than that of $E 2$, while the $1 / n$ values of the two compounds were very similar (Table 2). As the primary intermediate of microbial 


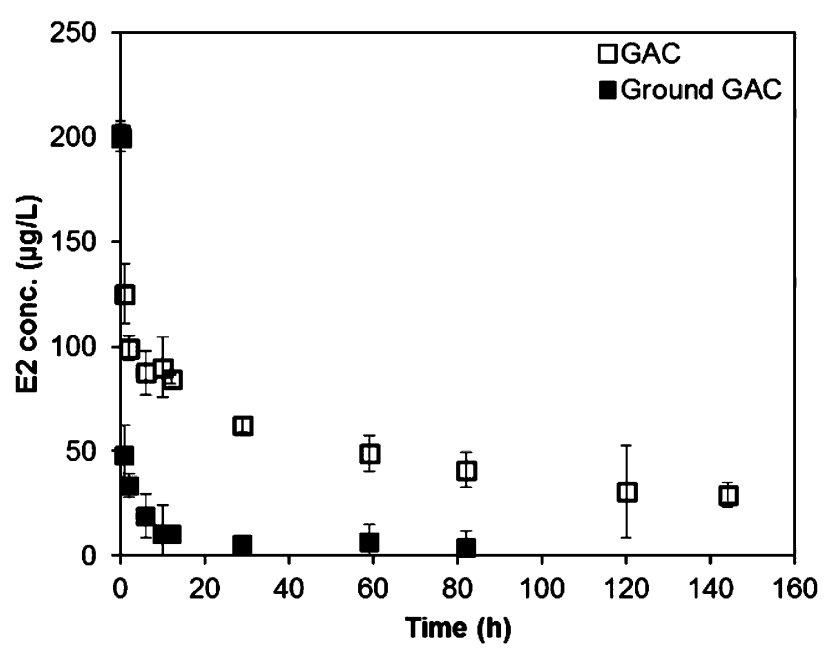

Figure 1. E2 adsorption kinetics of virgin GAC and virgin ground GAC.

$E 2$ degradation, $E 1$ is expected to coexist with $E 2$ in drinking water sources. In order to examine the adsorption behaviors of $E 1$ and $E 2$ in solutions where both compounds are present, a dual-solute experiment was conducted. Competitive adsorption was observed. Compared to their counterparts in the single-solute experiments, the $K_{F}$ of $E 1$ in the dual-solute experiment decreased by $52 \%$ and the $K_{F}$ of $E 2$ by $73 \%$. The difference between the $1 / n$ values from the single- and dual-solute experiments was not statistically significant for either compound based on a paired $t$-test.

The $K_{F}$ values of $E 1$ were higher than those of $E 2$ in both the single- and dual-solute experiments, indicating a higher GAC adsorption capacity for E1. This finding is consistent with a previous study, which concluded that the adsorption of $E 1$ onto activated carbon was $8 \%$ higher than that of $E 2$ due to the higher hydrophobicity of $E 1$ (Fukuhara et al., 2006). Because $E 2$ and $E 1$ share similar size and molecular structure and $E 1$ is more hydrophobic than $E 1$, the change of Gibbs free energy between free and adsorbed forms for $E 1$ is higher than that for $E 2$, leading to higher adsorption selectivity and capacity for $E 1$ (Klimenko et al., 2002). Therefore, it is not surprising that the results in Table 2 show that the adsorption capacity for $E 2$ significantly decreased in the presence of $E 1$. In order to evaluate $E 2$ removal in continuous flow systems, a laboratory-scale GAC reactor was built and operated.

\subsection{E2 removal in a GAC reactor}

A continuous flow GAC reactor was built in the laboratory and fed with $\mathrm{RO}$ water containing E2 only. Overall, the GAC operation phase was viewed as an abiotic phase, except that a low level of $E 2$ biodegradation was observed toward the end of the GAC phase. The influent $E 2$ concentration was monitored periodically and appeared to be stable at $20 \pm 3 \mu \mathrm{g} / \mathrm{L}$. E2 in the effluent was first observed above the MDL after only 1,819 BVs (or 15 days, Figure 3 middle panel). In the next 10,159 BVs (or 163 days), a series of EBCTs $(48,30,20,16$, and $4.8 \mathrm{~min})$ were tested by adjusting the surface loading rate to 2.6, 4.1, 6.1, 7.6 and $25.5 \mathrm{~L} /$

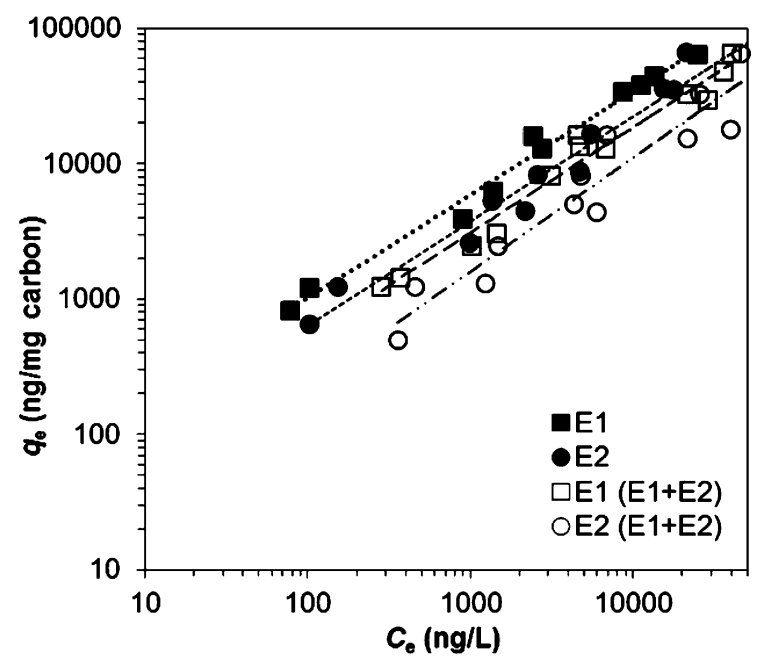

Figure 2. $E 1$ and $E 2$ adsorption isotherms of ground GAC in single- and dual-solute (i.e., $E 1+E 2$ ) solutions.

$\mathrm{m}^{2}$-min (Figure 3 top panel). After each change in EBCT, at least 396 BVs of water passed through the reactor before an effluent water sample was collected. Effluent $E 2$ concentrations appeared to be responding to the EBCT changes. Their values increased from 0.63 , to $2.2,2.72,4.38$ and $6.48 \mu \mathrm{g} / \mathrm{L}$, corresponding to the five EBCTs tested (i.e., 48, 30, 20, 16, and $4.8 \mathrm{~min}$ ). No change in effluent $\mathrm{DO}$ was observed during the GAC operation phase (Figure 3 bottom panel).

Given that the F400 GAC has a relatively high adsorption capacity for $E 2$ at the concentration range tested, the early leakage of $E 2$ in the effluent was likely due to a shallow mass transfer zone (MTZ). For a shallow MTZ, its initial portion often leaves a GAC column relatively quickly. Several studies reported that for contaminants at low levels (i.e. at low ng/L level) the mass transfer in external film diffusion is often the time limiting step, as the surface diffusion is often fast (Wolborska, 1999; Yu et al., 2009). Therefore, the shallow MTZ in this study likely resulted from the low external film diffusion of $E 2$ under the experimental condition. Natural organic matter (NOM) in water sources could further slow external film diffusion (Yu et al., 2009), hence, it is plausible to expect an early breakthrough of $E 2$ in a full-scale GAC filter with the presence of NOM. Given that an E2 concentration as low as $16 \mathrm{ng} / \mathrm{L}$ could cause negative ecological impacts, such as feminization of male fish (Imai et al., 2005), likely GAC adsorption alone will not be sufficient to keep effluent $E 2$ level at a safety level under continuous operation.

\subsection{Ammonium-stimulated microbial E2 degradation}

The addition of ammonium to the GAC reactor starting on Day 178 promoted microbial growth and stimulated microbial E2 degradation. Toward the end of 178 days of GAC operation, microbial activities developed inside the reactor, which was evidenced by the emergence of a microbial $E 2$ degradation intermediate, $E 1$, in reactor effluent. Because the reactor had never been intentionally seeded, the microbes in the reactor were likely introduced from the inhouse $\mathrm{RO}$ water, which was used to make the reactor influent, during the extended period of operation. In addition, 
Table 2. Freundlich isotherm parameters in single-solute and mixed-solute solutions.

\begin{tabular}{lcccc}
\hline Freundlich parameter & \multicolumn{2}{c}{ E1 } & & \multicolumn{2}{c}{ E2 } \\
\cline { 2 - 4 } & Single-solute & Dual-solute & Single-solute & Dual-solute \\
\hline$K_{F}(\mathrm{ng} / \mathrm{mg})(\mathrm{L} / \mathrm{ng})^{1 / n}$ & 29.84 & 14.22 & 18.06 & 4.78 \\
$1 / n($ dimensionless $)$ & 0.77 & 0.78 & 0.77 & 0.84 \\
$R^{2}$ & 0.99 & 0.97 & 0.97 & 0.91 \\
\hline
\end{tabular}

TOC was detected in the in-house RO water at low levels and was likely used as a substrate by the microbes in the reactor toward the end of the 178 days of operation. Previous studies showed that ammonia oxidizing bacteria in pure and mixed cultures were capable of degrading E2, e.g., $\mathrm{Ni}$ trosomonas europea could biodegrade E2 and E1 (Shi et al., 2004). Hence, on day $178,3.0 \mathrm{mg} / \mathrm{L} \mathrm{NH}_{4}^{+}-\mathrm{N}$ was pumped into the reactor influent to stimulate the growth of ammonia oxidizing bacteria.

Two distinct phases were observed in reactor performance after ammonium was added to the reactor and the GAC reactor was converted to a BAC reactor. In Phase 1 (Figure 4, Day 178-183) effluent E1 concentration increased from below the MDL to a peak value of $250 \mathrm{ng} / \mathrm{L}$. Concurrently, effluent TOC decreased from $0.3 \mathrm{mg}-\mathrm{C} / \mathrm{L}$ to $0.1 \mathrm{mg}-\mathrm{C} / \mathrm{L}$, effluent DO decreased from $7.8 \mathrm{mg} / \mathrm{L}$ to $3.7 \mathrm{mg} / \mathrm{L}$, and effluent $\mathrm{NH}_{4}^{+}$- $\mathrm{N}$ increased to $0.8 \mathrm{mg} / \mathrm{L}$ before it fell back. In Phase 2 (Figure 4, Day 183-240), effluent $E 2$ and $E 1$ concentrations dropped to below their respective MDLs. In the meantime, effluent $\mathrm{NH}_{4}^{+}$- $\mathrm{N}$ remained below its MDL, and effluent DO and TOC stabilized at $3.5 \mathrm{mg} / \mathrm{L}$ and $0.2 \mathrm{mg} / \mathrm{L}$, respectively. During this phase, ammonium in the reactor might be consumed by the microbial community as a nitrogen source, be utilized as an electron donor in nitrification, and/ or be adsorbed onto GAC surface (Hussain et al., 2007).

The effluent profiles during the transition from GAC to BAC suggest some important characteristics of the estrogen degrading populations in the reactor. Given that the RO water used to make the reactor influent did not contain detectable levels of estrogens, the fact that the bacteria originated from the in-house system accumulated in the $\mathrm{BAC}$ reactor and degraded estrogens suggests that bacteria in a system that has not been previously exposed to estrogens may process the enzymes related to estrogen degradation. In addition, the decrease of effluent E2 in Phase 1 suggests that $E 2$ degrading bacteria were being enriched in the BAC reactor. The increase of effluent E1 in Phase 1 suggests a lack of $E 1$ degrading bacteria in the reactor upon the start of the BAC process. Prior to the addition of ammonium, heterotrophic aerobes in the reactor used influent TOC as an electron donor, but their activity levels were limited due to the lack of nutrients. After Day 178, the heterotrophic aerobes used $\mathrm{NH}_{4}^{+}-\mathrm{N}$ as a nitrogen source and consumed more TOC (Figure 4).

The decreases of effluent E1 and E2 in Phase 2 suggest that $E 2$ and E1 degrading bacteria were gradually accumulated in the BAC reactor. The overlap of the effluent $E 1$ and E2 profiles in Phase 2 indicates two possibilities: (1) bacteria capable of degrading both $E 2$ and $E 1$ accumulated in the reactor, or (2) separate E2 and E1 degrading bacterial populations accumulated in the reactor at the same rate. Results in the next section support the second possibility.

\subsection{BAC operation with acetic acid and nitrate}

To better simulate surface water composition, on Day 240 $4.0 \mathrm{mg} / \mathrm{L} \mathrm{NH}_{3}^{-}-\mathrm{N}$ was added to replace $3.0 \mathrm{mg} / \mathrm{L} \mathrm{NH}_{4}^{+}-\mathrm{N}$ as the nitrogen source. $5.0 \mathrm{mg}-\mathrm{C} / \mathrm{L}$ acetic acid was added to reactor influent to simulate the readily-biodegradable portion of organic matters in natural water and to serve as an energy/carbon source for microbial growth in the reactor (Figure 5). In Phase 3, the reactor was operated with a 30min EBCT. The effluent E2 concentration was either close to or below the MDL, whereas E1 started to increase soon after the change in influent composition. Upon the start of the
Figure 3. Effects of the EBCT on effluent $E 2$ and DO concentrations of the GAC reactor. The influent $E 2$ and DO concentrations were $20 \mu \mathrm{g} / \mathrm{L}$ and $\sim 8 \mathrm{mg} / \mathrm{L}$, respectively.

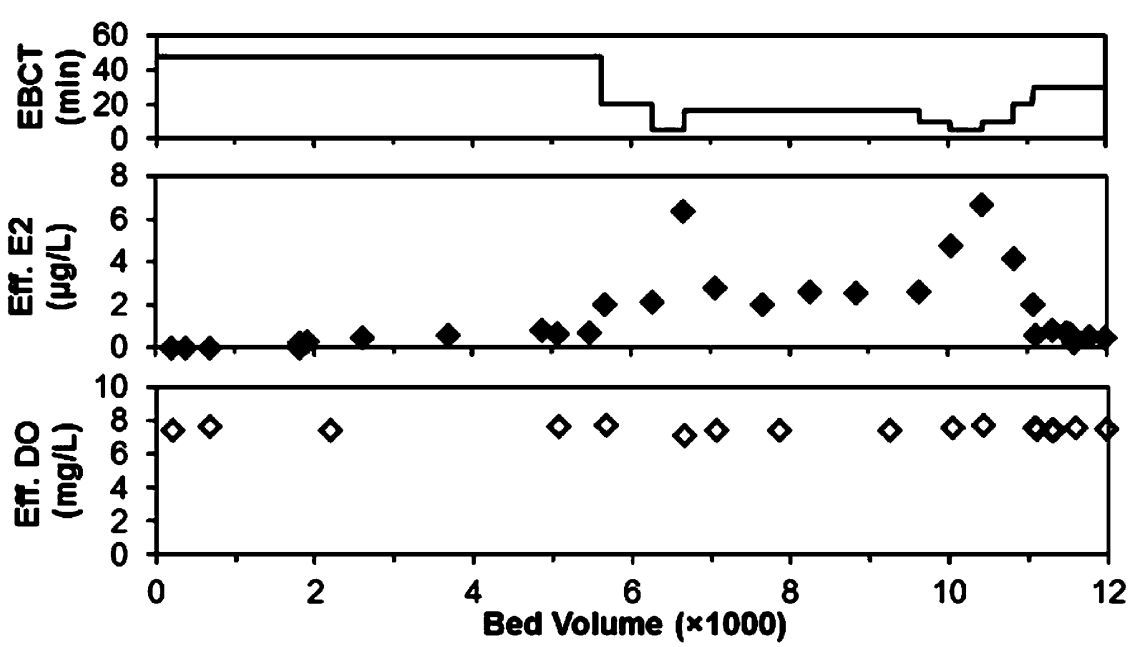




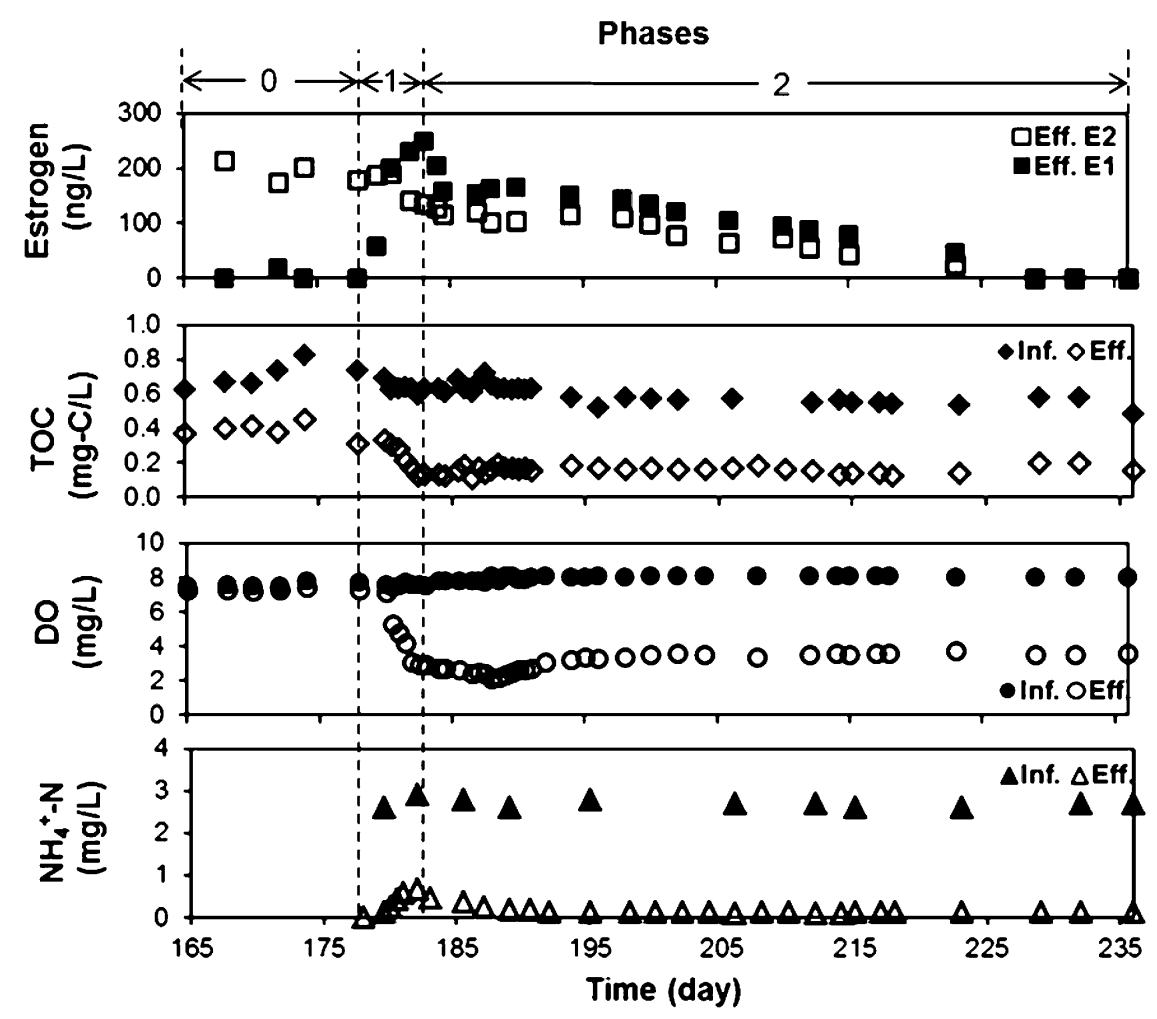

Figure 4. BAC reactor performance upon the addition of $\mathrm{NH}_{4}^{+}$into the reactor influent. 30 min EBCT was applied.

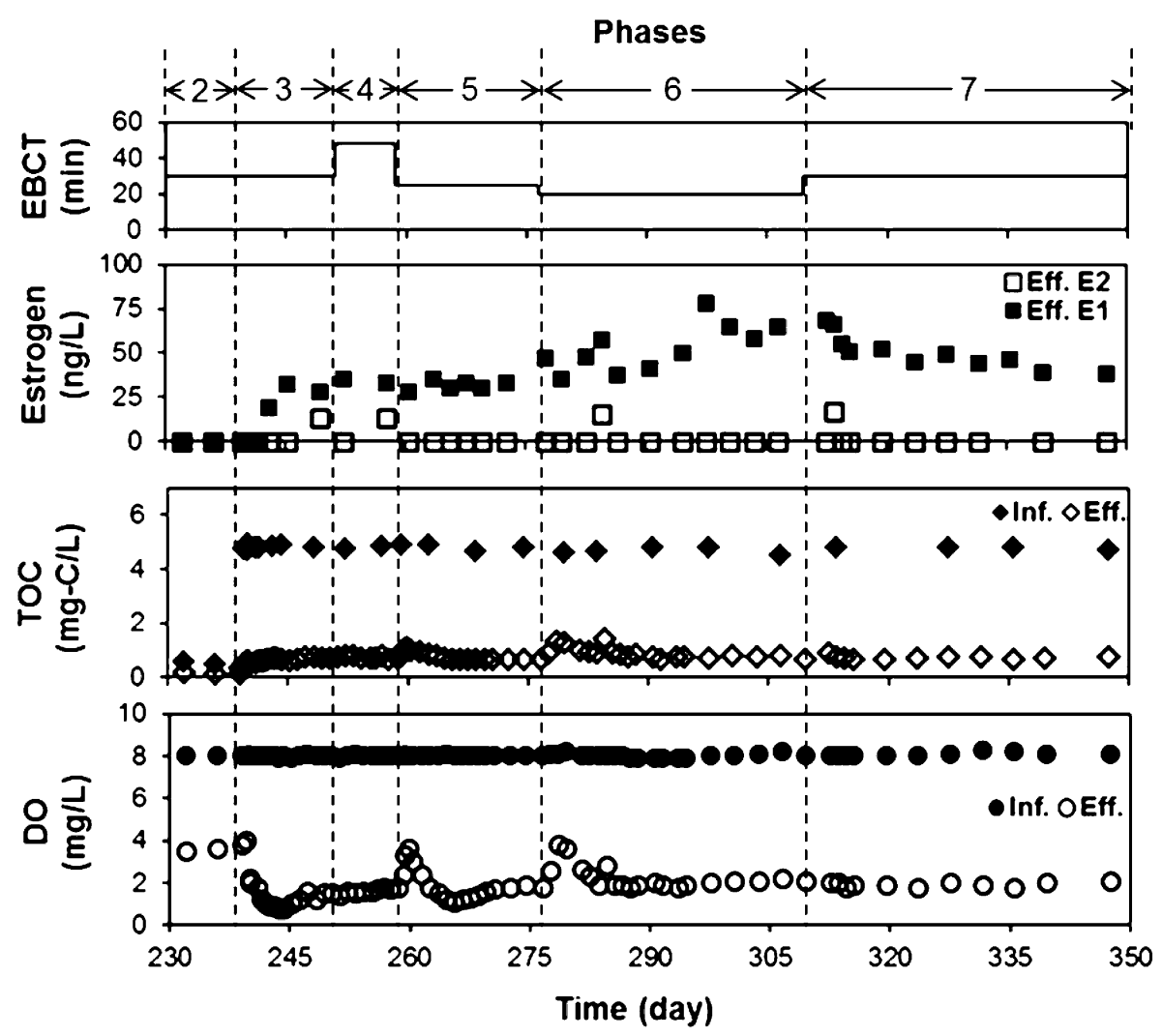

Figure 5. Performance of the BAC reactor after the influent was switched to synthetic surface water, in which acetic acid and nitrate were used to simulate the carbon/energy and nitrogen sources, respectively. 
change in influent composition, the BAC reactor consumed the majority of the influent TOC (primarily acetic acid) and DO. At the end of Phase 3 the effluent parameters appeared to reach quasi-steady state. In Phase 4 through 6, the EBCT was decreased from 48 to 25 and then to $20 \mathrm{~min}$. Each time the EBCT was decreased, the effluent DO increased and then dropped back down to near $2 \mathrm{mg} / \mathrm{L}$. During these three phases, the effluent $E 2$ concentration was not substantially impacted by the decreasing EBCTs, while the effluent $E 1$ concentration increased with decreasing EBCTs. No pronounced differences were observed in the effluent DO or TOC profiles across the three phases. No shorter EBCTs were tested due to the concern over increasing effluent $E 1$ concentration. EBCT was switched back to $30 \mathrm{~min}$ in Phase 7.

The results in Figure 5 have implications to estrogen removal in full-scale treatment systems. After the change in influent composition, effluent $E 1$ started to increase while effluent E2 was not significantly affected, suggesting that the two compounds were degraded by two separate microbial populations. Furthermore, the E1 degradation carried out by the $E 1$ degrading population seemed to rely on the presence of ammonium. In addition, compared to the difference in response to the change in influent composition (Phase 3), the differences in response of $E 1$ and $E 2$ degradations to decreasing EBCTs seemed more pronounced (Phases 4-6). This result is consistent with previous studies that suggested $E 1$ degradation was the time limiting step during $E 2$ biodegradation (Weber et al., 2005; Yu et al., 2007). The results in Figure 5 indicate that the presence of ammonium and sufficient contact time might be critical in achieving $E 1$ degradation.

\subsection{Comparison between GAC and BAC}

BAC showed a superior $E 2$ removal performance than GAC for all the EBCTs tested, primarily due to microbial degradation. E2 removal data from the GAC and the BAC operations were plotted against EBCTs in Figure 6. The removal data were calculated using effluent estrogen concentrations at quasi-steady state of each operation phase where the

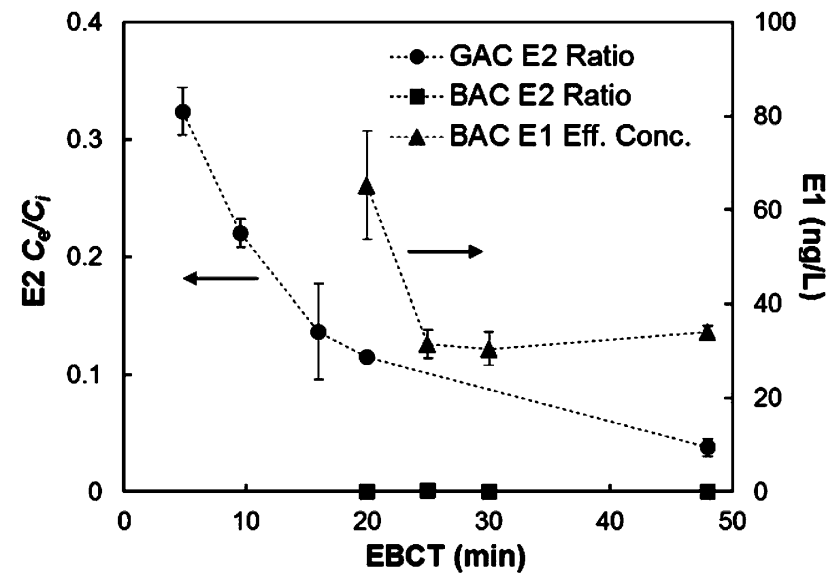

Figure 6. Estrogen removal efficacies of GAC and BAC (Phases 3-7) as a function of EBCT. $C_{e}$ and $C_{i}$ represent the effluent and influent $E 2$ concentrations, respectively. variations of effluent concentrations were within $6 \%$. Complete $E 2$ removal $\left(C_{\mathrm{e}} / C_{\mathrm{i}}=0\right)$ was achieved during the BAC treatment with all the EBCTs tested. As a comparison, the $C_{\mathrm{e}} / C_{\mathrm{i}}$ ratio of $E 2$ during the GAC treatment increased from 0.04 to 0.32 as EBCT decreased from 48 to $4.8 \mathrm{~min}$. Assuming no mass transfer limitations and no desorption of $E 2$, it was estimated that only $1 \%$ of the total adsorption capacity of the activated carbon bed was consumed with the 348 days of operation (Figure S1). This calculation shows that the carbon adsorption capacity during the BAC operation phase was comparable to that during the GAC operation phase, suggesting that the difference in estrogen removal between the two phases was primarily due to microbial degradation. In addition, adsorption of estrogens to biofilm through hydrophobic interactions might also contribute to $E 2$ removal during BAC operation. Adsorption of $E 2$ to biomass was demonstrated in an activated sludge study, in which the adsorption could reach equilibrium within $10 \mathrm{~min}$ and the adsorption capacity was considered moderate at low estrogen concentrations (Ren et al., 2007).

While E2 was completely removed, E1 appeared in effluent during BAC operation. Complete $E 1$ removal was only achieved when $\mathrm{NH}_{4}^{+}$was added to the reactor. After $\mathrm{NH}_{4}^{+}$was replaced with $\mathrm{NH}_{3}^{-}$, effluent $E 1$ stabilized between 35 and $40 \mathrm{ng} / \mathrm{L}$ when EBCTs were set between 25 and $48 \mathrm{~min}$. Our previous study showed that changes in nutrient conditions could affect the structure and function of the microbial community of a bioreactor (Li et al., 2010). Hence, it is expected that the change in nitrogen source affected the microbial community in the BAC reactor. Indeed, in another study, we observed that $E 1$ degrading bacteria were outcompeted in the reactor after $\mathrm{NH}_{4}^{+}$was replaced by $\mathrm{NH}_{3}^{-}$(manuscript in preparation). Because the estrogenic potency of $E 1$ was $14 \%$ of that of $E 2$ (Metcalfe et al., 2001), the overall estrogenicity of the water decreased. This study indicated that further optimizations of BAC reactors to remove estrogens should be focused on promoting the abundance and activities of $E 1$ degrading bacteria.

\section{Conclusions}

The present study investigated the $E 2$ and $E 1$ adsorption characteristics on GAC and evaluated the removal and E2 and $E 1$ in a continuously operated GAC reactor, which was later converted to a $\mathrm{BAC}$ reactor. The main conclusions are as follows:

1 The adsorption isotherm experiment showed that the GAC had a higher adsorption capacity for $E 1$ than for $E 2$, and revealed competitive adsorption between $E 1$ and $E 2$.

2 Early $E 2$ leakage in reactor effluent occurred during the continuous operation of a GAC reactor. E2 removal in the GAC reactor benefited from longer EBCTs, however, complete $E 2$ removal could not be achieved at even the longest EBCT tested (i.e., $48 \mathrm{~min}$ ).

3 Ammonium addition enhanced biological activities and resulted in complete $E 1$ and $E 2$ removals in about 50 days.

4 When ammonium was replaced by nitrate and acetic acid was used to simulate the natural organic matters 
in influent water, microbial E2 degradation was not affected, whereas microbial E1 degradation was adversely affected.

5 When the EBCT was decreased, microbial E2 degradation was not affected in the BAC reactor, while microbial E1 degradation was deteriorated.

6 BAC showed superior performance to GAC in removing estrogenicity from water. Future efforts in reactor optimization should be focused on improvement of microbial E1 degradation.

Acknowledgment - This work was financially supported by the UNL startup fund to XL. The authors thank the technical supports from Dan Snow and David Cassada at the UNL Water Sciences Laboratory on GC-MS analyses.

\section{Appendix}

Supplementary material (Figures S1 \& S2) follow the References.

\section{References}

Benotti, M.J., Stanford, B.D., Wert, E.C., Snyder, S.A., 2009a. Evaluation of a photocatalytic reactor membrane pilot system for the removal of pharmaceuticals and endocrine disrupting compounds from water. Water Research 43 (6), 1513-1522.

Benotti, M.J., Trenholm, R.A., Vanderford, B.J., Holady, J.C., Stanford, B.D., Snyder, S.A., 2009b. Pharmaceuticals and endocrine disrupting compounds in US drinking water. Environmental Science \& Technology 43 (3), 597-603.

Cartinella, J.L., Cath, T.Y., Flynn, M.T., Miller, G.C., Hunter, K.W., Childress, A.E., 2006. Removal of natural steroid hormones from wastewater using membrane contactor processes. Environmental Science \& Technology 40 (23), 7381-7386.

EPA, U., 1984. Definition and Procedure for the Determination of the Method Detection Limit, Revision 1.11. U.S. Environmental Protection Agency. Code of Federal Regulations, 40 CFP Part 136, 554.

EPA US, 2011. Drinking Water Contaminant Candidate List 3. http://water.epa.gov/scitech/drinkingwater/dws/ccl/.

Fujii, K., Kikuchi, S., Satomi, M., Ushio-Sata, N., Morita, N., 2002. Degradation of 17 beta-estradiol by a gram-negative bacterium isolated from activated sludge in a sewage treatment plant in Tokyo, Japan. Applied and Environmental Microbiology 68 (4), 2057-2060.

Fukuhara, T., Iwasaki, S., Kawashima, M., Shinohara, O., Abe, I., 2006. Adsorbability of estrone and 17 beta-estradiol in water onto activated carbon. Water Research 40 (2), 241-248.

Hansen, K.M.S., Andersen, H.R., Ledin, A., 2010. Ozonation of estrogenic chemicals in biologically treated sewage. Water Science and Technology 62 (3), 649-657.

Holbrook, R.D., Novak, J.T., Grizzard, T.J., Love, N.G., 2002. Estrogen receptor agonist fate during wastewater and biosolids treatment processes: a mass balance analysis. Environmental Science \& Technology 36 (21), 4533-4539.
Hussain, S., Aziz, H.A., Isa, M.H., Adlan, M.N., Asaari, F.A.H., 2007. Physico-chemical method for ammonia removal from synthetic wastewater using limestone and GAC in batch and column studies. Bioresource Technology 98 (4), 874-880.

Hutchins, S.R., White, M.V., Hudson, F.M., Fine, D.D., 2007. Analysis of lagoon samples from different concentrated animal feeding operations (CAFOs) for estrogens and estrogen conjugates. Environmental Science \& Technology 41 (20), 7192, vol. 41, pg 738, 2007.

Imai, S., Koyama, J., Fujii, K., 2005. Effects of 17 beta-estradiol on the reproduction of Java-medaka (Oryzias javanicus), a new test fish species. Marine Pollution Bulletin 51 (8e12), 708-714.

Kim, S.D., Cho, J., Kim, I.S., Vanderford, B.J., Snyder, S.A., 2007. Occurrence and removal of pharmaceuticals and endocrine disruptors in South Korean surface, drinking, and waste waters. Water Research 41 (5), 1013-1021.

Klimenko, N., Winther-Nielsen, M., Smolin, S., Nevynna, L., Sydorenko, J., 2002. Role of the physico-chemical factors in the purification process of water from surface-active matter by biosorption. Water Research 36 (20), 5132-5140.

Kuster, M., Diaz-Cruz, S., Rosell, M., de Alda, M.L., Barcelo, D., 2010. Fate of selected pesticides, estrogens, progestogens and volatile organic compounds during artificial aquifer recharge using surface waters. Chemosphere 79 (8), 880-886.

Labadie, P., Budzinski, H., 2005. Determination of steroidal hormone profiles along the Jalle d'Eysines River (near Bordeaux, France). Environmental Science \& Technology 39 (14), 5113-5120.

Li, F.S., Yuasa, A., Tanaka, H., Katamine, Y., 2008. Adsorption and biotransformation of 17 beta-estradiol in biological activated carbon adsorbers. Adsorption-Journal of the International Adsorption Society 14 (2e3), 389-398.

Li, X., Upadhyaya, G., Yuen, W., Brown, J., Morgenroth, E., Raskin, L., 2010. Changes in the structure and function of microbial communities in drinking water treatment bioreactors upon addition of phosphorus. Applied and Environmental Microbiology 76 (22), 7473-7481.

Loos, R., 2010. Pan-European survey on the occurance of selected polar organic persistent pollutants in ground water. Water Research 44, 4115.

Maniero, M.G., Bila, D.M., Dezotti, M., 2008. Degradation and estrogenic activity removal of 17 beta-estradiol and 17 alphaethinylestradiol by ozonation and $\mathrm{O}-3 / \mathrm{H} 2 \mathrm{O} 2$. Science of the Total Environment 407 (1), 105-115.

Metcalfe, C.D., Metcalfe, T.L., Kiparissis, Y., Koenig, B.G., Khan, C., Hughes, R.J., Croley, T.R., March, R.E., Potter, T., 2001. Estrogenic potency of chemicals detected in sewage treatment plant effluents as determined by in vivo assays with Japanese medaka (Oryzias latipes). Environmental Toxicology and Chemistry 20 (2), 297-308.

Mitsch, W.J., Day, J.W., Zhang, L., Lane, R.R., 2005. Nitratenitrogen retention in wetlands in the Mississippi river basin. Ecological Engineering 24 (4), 267-278.

Nerenberg, R., Rittmann, B.E., Najm, I., 2002. Perchlorate reduction in a hydrogen-based membrane-biofilm reactor. Journal - American Water Works Association 94 (11), 103-114. 
Purdom, C.E., H, P.A., Bye, V.J., Eno, N.C., Tyler, C.R., Sumpter, J.P., 1994. Estrogenic effects of effluents from sewage treatment works. Journal of Chemical Ecology 8, 275-285.

Putz, A.R.H., Losh, D.E., Speitel, G.E., 2005. Removal of nonbiodegradable chemicals from mixtures during granular activated carbon bioregeneration. Journal of Environmental Engineering-ASCE 131 (2), 196-205.

Ren, Y.X., Nakano, K., Nomura, M., Chiba, N., Nishimura, O., 2007. A thermodynamic analysis on adsorption of estrogens in activated sludge process. Water Research 41 (11), 2341-2348.

Rutishauser, B.V., Pesonen, M., Escher, B.I., Ackermann, G.E., Aerni, H.R., Suter, M.J.F., Eggen, R.I.L., 2004.Comparativeanalysis of estrogenic activity in sewage treatment plant effluents involving three in vitro assays and chemical analysis of steroids. Environmental Toxicology and Chemistry 23 (4), 857-864.

Shappell, N.W., Vrabel, M.A., Madsen, P.J., Harrington, G., Billey, L.O., Hakk, H., Larsen, G.L., Beach, E.S., Horwitz, C.P., Ro, K., Hunt, P.G., Collins, T.J., 2008. Destruction of estrogens using Fe-TAML/peroxide catalysis. Environmental Science \& Technology 42 (4), 1296-1300.

Shareef, A., Angove, M.J., Wells, J.D., 2006. Optimization of silylation using N-methyl-N-(trimethylsilyl)- trifluoroacetamide, N,O-bis-(trimethylsilyl)- trifluoroacetamide and N(tert-butyldimethylsilyl)-Nmethyltrifluoroacetamide for the determination of the estrogens estrone and 17 alpha-ethinylestradiol by gas chromatography-mass spectrometry. Journal of Chromatography A 1108 (1), 121-128.

Shi, J., Fujisawa, S., Nakai, S., Hosomi, M., 2004. Biodegradation of natural and synthetic estrogens by nitrifying activated sludge and ammonia-oxidizing bacterium Nitrosomonas europaea. Water Research 38 (9), 2323-2330.

Speitel, G.E., Digiano, F.A., 1987. The bioregeneration of Gac used to treat micropollutants. Journal - American Water Works Association 79 (1), 64-73.

Stanford, B.D., Weinberg, H.S., 2010. Evaluation of on-site wastewater treatment technology to remove estrogens, nonylphenols, and estrogenic activity from wastewater. Environmental Science \& Technology 44 (8), 2994-3001.
Vader, J.S., van Ginkel, C.G., Sperling, F.M.G.M., de Jong, J., de Boer, W., de Graaf, J.S., van der Most, M., Stokman, P.G.W., 2000. Degradation of ethinyl estradiol by nitrifying activated sludge. Chemosphere 41 (8), 1239-1243.

Wang, H.X., Ho, L., Lewis, D.M., Brookes, J.D., Newcombe, G., 2007. Discriminating and assessing adsorption and biodegradation removal mechanisms during granular activated carbon filtration of microcystin toxins. Water Research 41 (18), 4262-4270.

Weber, S., Leuschner, P., Kampfer, P., Dott, W., Hollender, J., 2005. Degradation of estradiol and ethinyl estradiol by activated sludge and by a defined mixed culture. Applied Microbiology and Biotechnology 67 (1), 106-112.

Wolborska, A., 1999. External film control of the fixed bed adsorption. Chemical Engineering Journal 73 (2), 85-92.

Yi, T., Harper, W.F., 2007. The link between nitrification and biotransformation of 17 alpha-ethinylestradiol. Environmental Science \& Technology 41 (12), 4311-4316.

Yoon, Y., Westerhoff, P., Snyder, S.A., Wert, E.C., Yoon, J., 2007. Removal of endocrine disrupting compounds and pharmaceuticals by nanofiltration and ultrafiltration membranes. Desalination 202 (1-3), 16-23.

Yoshimoto, T., Nagai, F., Fujimoto, J., Watanabe, K., Mizukoshi, H., Makino, T., Kimura, K., Saino, H., Sawada, H., Omura, H., 2004. Degradation of estrogens by Rhodococcus zopfii and Rhodococcus equi isolates from activated sludge in wastewater treatment plants. Applied and Environmental Microbiology 70 (9), 5283-5289.

Yu, C.P., Roh, H., Chu, K.H., 2007. 17 beta-estradiol-degrading bacteria isolated from activated sludge. Environmental Science \& Technology 41 (2), 486-492.

Yu, Z., Peldszus, S., Huck, P.M., 2009. Adsorption of selected pharmaceuticals and an endocrine disrupting compound by granular activated carbon. 1. Adsorption capacity and kinetics. Environmental Science \& Technology 43 (5), 1467-1473.

Zhang, Y.P., Zhou, J.L., 2005. Removal of estrone and 17 betaestradiol from water by adsorption. Water Research 39 (16), 3991-4003. 

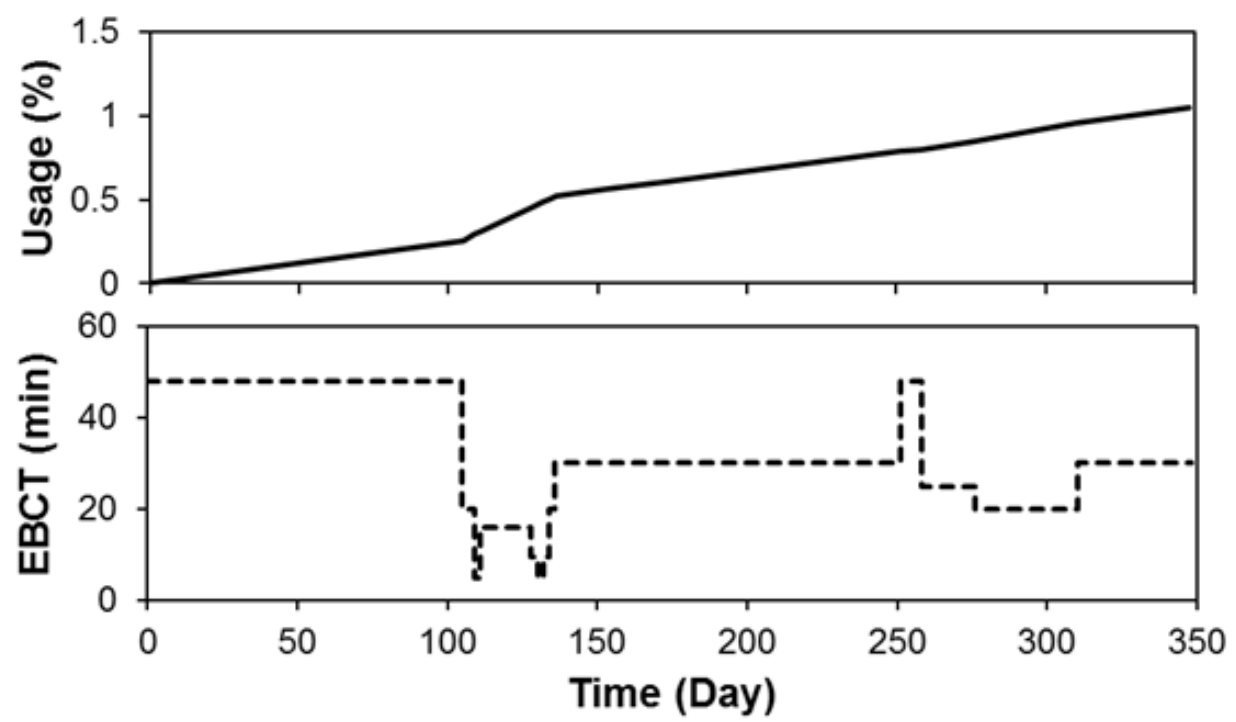

Figure S1. Assuming no mass transfer limitations, no desorption, and biodegradation, the adsorption capacity usage of the activated carbon bed was less than $1 \%$ throughout the GAC and BAC operation phases. 


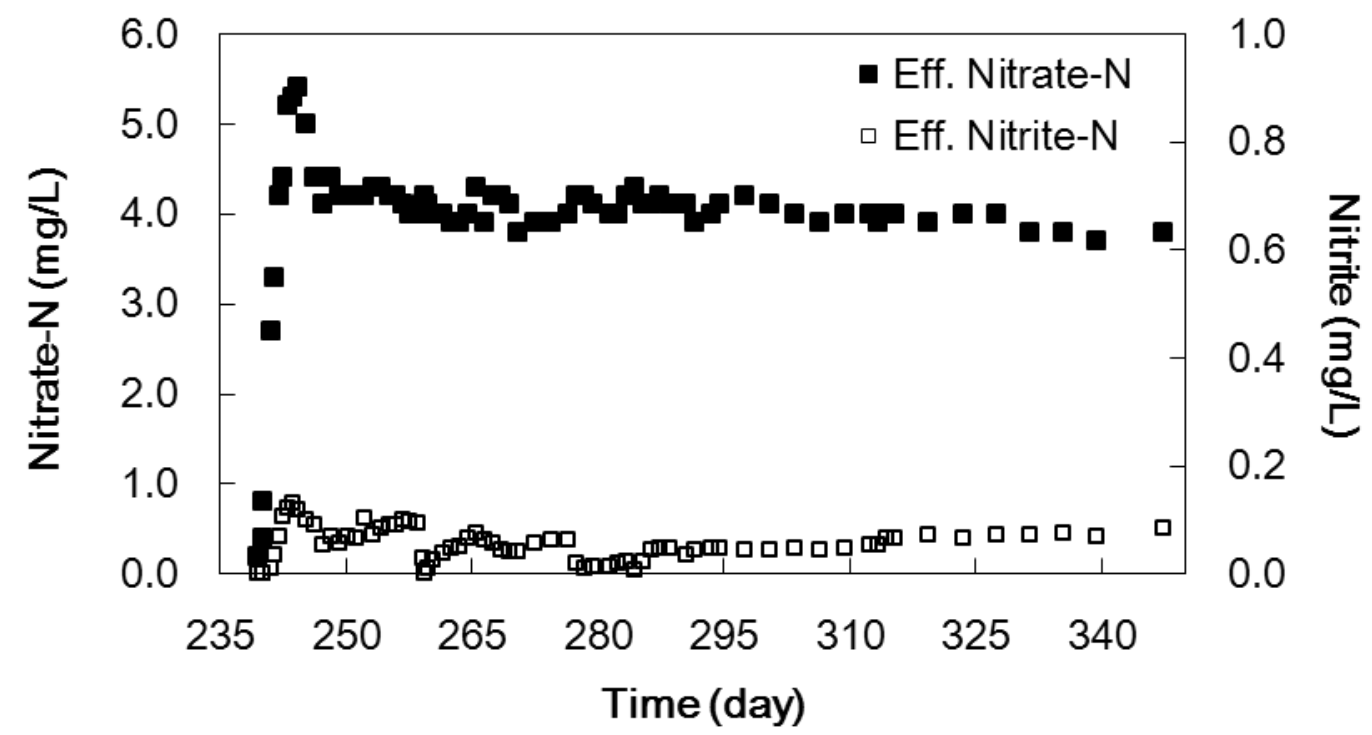

Figure S2. Effluent nitrate and nitrite concentration profiles during Phases 3 - 7 of the BAC operation. 